The Egyptian Journal of Biochemistry \& Molecular Biology VOL 37 (N.1 \& 2) 17-36 December. 2019

\title{
EVALUATION OF RECEPTOR FOR ADVANCED GLYCATION END PRODUCT /HIGH-MOBILITY GROUP BOX 1 (RAGE/HMGB1) EXPRESSION STATUS AND ITS PROGNOSTIC VALUE IN BREAST CANCER
}

\author{
Shimaa El-Shafey Soliman ${ }^{1}$, Mona Salah El-din Habib ${ }^{1}$,Marwa \\ M.Serag El-Dien ${ }^{2}$, Suzy Fawzy Gohar ${ }^{3}$ and Suzan.A.Alhassanin ${ }^{3}$ \\ ${ }^{1}$ Medical Biochemistry and Molecular Biology Department, \\ ${ }^{2}$ Pathology and ${ }^{3}$ Clinical Oncology Departments, Faculty of \\ Medicine, Menoufia University, Egypt
}

Received 7/11/2018 - Accepted 11/12/2018

\begin{abstract}
Sucess in breast cancer treatment is not built only on diversity but on clinical relevance to tumor pathogenesis. So, gathering of many prognositic biomarkers involved in cancer progression could yield new treatment modalities in order to maitain good quality of life for patients.The receptor for advanced glycation end product (RAGE) and its ligand the high-mobility group box 1 (HMGB1) protein seem to play a role in many cancers, their cross-talk affects breast cancer behaviour. The aim of this study was to investigate the tissue RAGE and HMGB1 expression levels and their association with clinicopathological features and overall survival in breast cancer patients.Tissue RAGE and HMGB1 mRNA levels were measured by real time-polymerase chain reaction (RT-PCR). Results showed tissue RAGE and HMGB1 displayed significant higher expression levels compared to benign group. RAGE and HMGB1 expression levels in breast cancer tissues were significantly associated with high tumour grade , lymph node metastasis ,stage III wih no significant relation to the molecular type of tumor nor overall survival. RAGE-HMGB1 system seems to be linked to breast cancer which may represent a prognostic biomarker of clinical and theraputic significance.
\end{abstract}

Key words: Breast cancer, RAGE, HMGB1, RT-PCR .

${ }^{\star}$ Correspondence Aauthor (dr.shelshafey2010@yahoo.com) 


\section{INTRODUCTION}

worldwide and among women, breast cancer is the most frequent malignancy with high mortality rate (Bond et al., 2018). Breast cancer ranks as number one among all malignant tumors in Egypt (Stapleton et al., 2011). Metastasis, the causaive agent of breast cancer-related mortalities, is not fully understood (Zheng et al., 2017). Therefore, identification of potential biomarkers linked to tumor proliferation and metastasis that could predict prognosis and conistitute a therapeutic target, is highly required.

Receptor for advanced glycation end product (RAGE), a member of the immunoglobulin superfamily, is a transmembrane multiligand receptor encoded by gene on chromosome 6p21.3 (Sparvero et al., 2009). The extracellular domain of RAGE, ligand binding part, contains one variable like (V) and two constant-like (C) type domains. The $\mathrm{V}$ domain poses two $\mathrm{N}$-glycosylation sites. The cytoplasmic tail of RAGE is responsible for intracellular signaling transduction (He et al., 2017). RAGE communicates with several ligands including advanced glycation end products, HMGB1 (Bierhaus et al., 2005).

HMGB1 belongs to the high-mobility group (HMG) protein family that was first described by Goodwin et al .,1973. HMGB1 is a multifuncional protein with multiple sites of existance. Within the nucleus, as a DNA binding protein, it is concerned with regulation of replication, transcription, DNA repair, recombination and genomic stability (Sohun and shen, 2016).

Release of HMGB1 is mediated by passive release from necrotic cells or active release from activated immune cells (Wittwer et al., 2013). Once released, it carries on its extracellular functions as a damage-associated molecular pattern molecule (DAMP) by interaction with several receptors, notably RAGE (Rai, 2018). RAGE, beside being a fundamental partner for HMGB1-induced cell proliferation, migration, inflammation and angiogenesis, it 
provides a functional platform for comunication with other HMGB1 receptors (Kang et al., 2013).

Growing evidences have demonstrated that RAGE orchestrates with its ligand HMGB1 to promote growth and metastasis of multiple tumors (Dhumale et al., 2015) This receptor-ligand pair is engaged in each of the ten hallmarks that tumor raised on, by initiating a cascade of signaling pathways controlling diverse aspects of tumor biology. Although, it is well recognized that HMGB1 play a paradoxical role in cancer, either as a promotor or a supressor factor (Rai, 2018), its role in breast cancer still confers confusion (Sun et al., 2015, Wu et al., 2016).

The aim of this study is to investigated the tissue expression levels of RAGE and HMGB1 and evaluate their association with the clinico-pathological features of breast cancer patients.

\section{MATERIALS AND METHODS}

This prospective case control study was carried out at Medical Biochemistry and Molecular Biology and Pathology Departments, Faculty of medicine, Menoufia University. It was performed on 68 cases of modified radical mastectomy specimens diagnosed as an invasive duct carcinoma (IDC) (malignant group), not otherwise specified and 63 cases of breast biopsy diagnosed as benign breast lesions including fibroadenoma and fibrocystic disease (control group). None of these patients were treated with radiotherapy or chemotherapy. These cases were received in Pathology Department, Faculty of medicine in the period between January 2015 and August 2016. Fresh part of the tumor mass was collected in an eppendorf tube and kept at $-80^{\circ} \mathrm{c}$ for further RNA extraction and RT-PCR for both RAGE and HMGB1 expression level. Slices from the tumor mass were taken and immersed in formalin and was submitted to routine tissue processing ending with paraffin embedded blocks formation. Tumors were graded according to the criteria of Nottingham modification in the Bloom-Richardson system (Elston and Ellis, 
1991). Tumor staging was performed according to Tumor Node Metastasis (TNM) staging system (Edge et al., 2010). According to the imunohistochemistry results of ER, PR and HER2/neu, the cases were classified into:

-Luminal subtype: positive ER and/or PR and negative HER 2/neu.

-HER 2/neu positive subtype: negative ER, negative PR and positive HER2/neu.

-Triple negative (TN) subtype: negative ER, negative PR and negative HER 2 neu.( Goldhirsch et al.,2011). For statistical purposes, tumors with grade 1 and 2 were lumped in one group, tumors with T3 and T4 stages were lumped in one group. Also, cases with stage I and II were lumped together. The patients were followed until last follow up date August 2016. The median follow-up time was 25 months. This study was approved by ethical committee of Faculty of Medicine, Menoufia University and a written consent was obtained from all subjects before the study.

\section{Assay of RAGE and HMGB1 mRNA expression levels:}

RNA extraction from breast tissue: Total RNA was extracted from specimens using the QIAamp RNA Blood MiniKit (Qiagen, USA) according to manufacturer's specifications (Wang et al., 2000). The purity of RNA was determined by measuring its absorbance at 260 $\mathrm{nm}$ (A260). Absorbance readings should be greater than 0.15 to ensure significance. The ratio between the absorbance value at 260 and $280 \mathrm{~nm}$ (A260/A280) gives an estimate of RNA purity. (A260/A280) ratio greater than 1.6 was accepted (Dorak, 2004).

Two-step RT-PCR: For reverse transcription step, a reverse transcriptase kit (SensiFAST cDNA synthesis kit, Bioline Reagents Ltd, United Kingdom) was used for complementary DNA (cDNA) synthesis on 2720 thermal cycler (Singapore). For cDNA synthesis, RNA $(10 \mu \mathrm{l})$ was reverse transcribed in a final volume of $20 \mu \mathrm{l}$ containing $1 \mu 1$ of reverse transcriptase enzyme, $4 \mu$ of $5 x$ TransAmp buffer and $5 \mu 1$ of DNase/RNase free water. The samples were incubated at $25^{\circ} \mathrm{C}$ for $10 \mathrm{~min}$ (primer annealing), and $42^{\circ} \mathrm{C}$ for 15 min (reverse transcription). Reverse transcriptase was then 
inactivated by heating at $85^{\circ} \mathrm{C}$ for $5 \mathrm{~min}$. All products were stored at $-20^{\circ} \mathrm{C}$ till the next step. For cDNA amplification: A relative quantification of RAGE and HMGB1 mRNA expression normalized to the endogenous reference gene $\beta$-actin was performed by realtime PCR (RT-PCR), using the $2 x$ SensiFAST ${ }^{\text {TM }}$ SYBR ${ }^{\circledR}$ Lo-ROX Kit (Bioline Reagents Ltd.), on Applied Biosystems 7500 Real-Time PCR System. RAGE primers were: 5'AAACATCACAGCCCGGATTG-'3 (forward) and 5'TCCGGCCTGTGTTCAGTTTCT- 3' (reverse) (Wang et al., 2015). HMGB1 primers were: 5'-ATATGGCAAAAGCGGACAAG-'3 (forward) and5'- GCAACATCACCAATGGACAG- 3' (reverse) (Wang et al., 2013). $\beta$-actin primers were: 5'GGCGGCACCACCATGTACCCT-3' (forward) and 5'AGGGGCCGGACTCGTCATACT-3' (reverse). Specificity of the primers was verified using Primer BLAST program provided by NCBI. The PCR reaction was setup with $25 \mu$ of final reacion volume consisting of $12.5 \mu \mathrm{l}$ of $2 \mathrm{x}$ SensiFAST ${ }^{\text {TM }}$ SYBR ${ }^{\circledR}$ Lo ROX Master Mix, $1 \mu \mathrm{l}$ of each target primer (Sigma), $5.5 \mu \mathrm{l}$ of DNase/RNase free water and $5 \mu \mathrm{l}$ of cDNA. Thermal cycling conditions comprised a $10 \mathrm{~min}$ at $95^{\circ} \mathrm{C}$, followed by 45 cycles at $95^{\circ} \mathrm{C}$ for $15 \mathrm{sec}$, and $60^{\circ} \mathrm{C}$ for $1 \mathrm{~min}$. For relative quantification of the results, the comparative cycle threshold $(\mathrm{Ct})$ method was used. Analysis was performed using Applied Biosystems7500, software version 2.0.1. The relative expressions of RAGE and HMGB1 were calculated using the comparative $\mathrm{Ct}$ method $(2-\Delta \Delta \mathrm{Ct})$. Each run was completed using melting curve analysis to confirm specificity of the amplification and absence of primer dimmers (figure 1 and 2). 


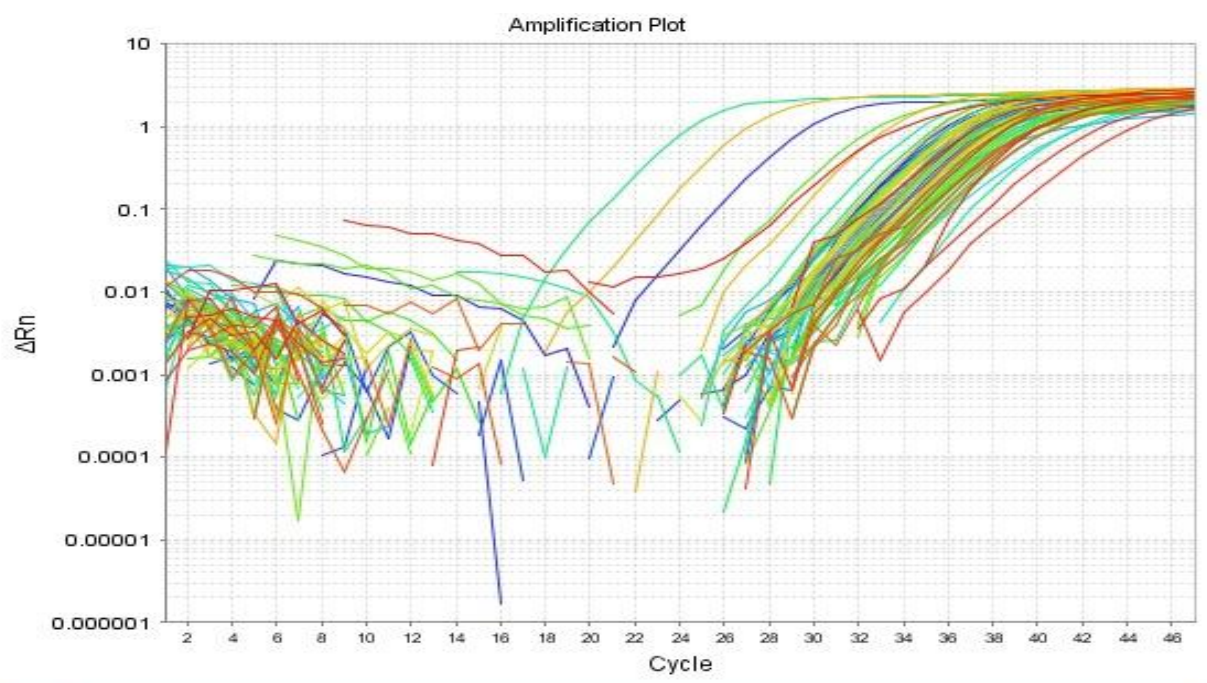

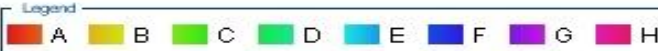

Figure(1): Amplification plot of RAGEexpression

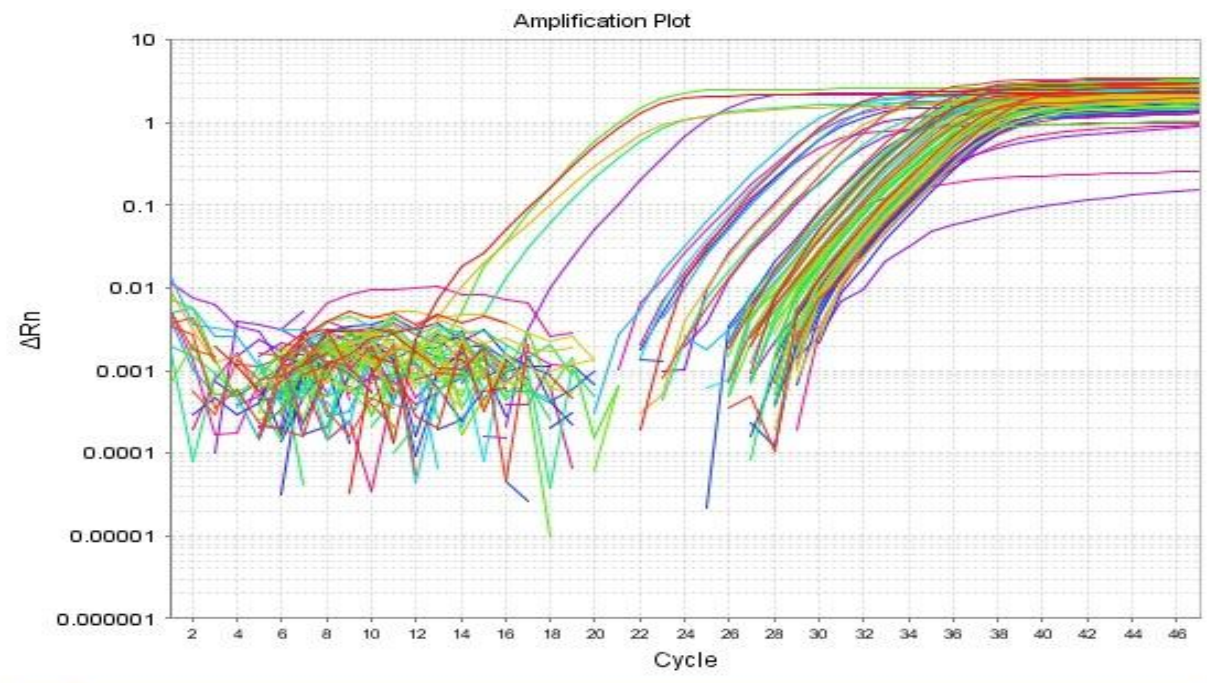

$\left[\begin{array}{lllll}\text { Legend } & \text { B } & \text { C } & \text { D } & \text { E }\end{array}\right.$

Figure (2): Amplification plot of HMGB1 expression 


\section{Statistical Analysis}

Data were collected, tabulated, and statistically analyzed using a personal computer with the "statistical package for the social sciences" (SPSS) version 23. All data were expressed as median,range, number and percent. Mann-Whitney (U) and Kruskal wallis tests were used for comparisons between quantitative variables. Spearman correlation coefficient (r) were used to assess the correlation between two quantitative variants. $\mathrm{P} \leq 0.05$ was considered significant.

\section{RESULTS}

The sixty-eight breast cancer patients were stratified according to age, tumor size, differentiation grade, lymphatic metastasis, and TNM stage and molecular type. All malignant cases were females. Their age ranged between 21 and 82 years (mean, 48.9 years). The tumor size ranged between 1 and $7.4 \mathrm{~cm}$ in maximal dimension. According to the differentiation grade, most of the patients were grade $2(76.5 \%)$. In relation to $\mathrm{T}$ stage, $27.9 \%, 55.9 \%, 13.3 \%$ and $2.9 \%$ belonged to $\mathrm{T} 1$, T2, T3 and T4 stages, respectively. Regarding nodal status, $92.6 \%$ of patients showed lymph node involvement. With reference to molecular subtyping, $42.9 \%$ of patients were luminal, $30.9 \%$ were Her-2 positive and $26.5 \%$ belonged to triple negative category. Nearby carcinoma in-situ component was found in $13.2 \%$ of the breast cancer patients as shown in (Table 1). The mRNA expression levels of both RAGE and HMGB1 were significantly higher in breast cancer tissues compared to benign breast diseases cases $(\mathrm{p}<0.001)$ (Table 2). 
There was significant positive linear correlation between RAGE and HMGB1 mRNA expression levels in breast cancer patients (spearman correlation coefficient $r=0.92, p<0.001$ ) (figure 3). Tissue mRNA expression levels of both RAGE and HMGB1 were significantly associated with patients showing high differentiation grade $(\mathrm{p}<0.001)$, advanced tumor stage $(\mathrm{T} 3$ and $\mathrm{T} 4)(\mathrm{p}<0.001), \mathrm{N} 3$ status $(\mathrm{p}<0.001)$, stage III $(\mathrm{p}<0.001)$ and with presence of in-situ component $(\mathrm{p}=0.004)$. Moreover, Both tissue RAGE and HMGB1 mRNA expression levels exhibited positive linear correlation with tumor size and number of positive lymph nodes $(\mathrm{p}<0.001)$, but no association was found between them and patient age (Tables $3 \& 4$ ). Mean overall survival time was 24.7 months (mean \pm SD $=24.7 \pm 2.6$, median 25 months). Overall survival ranges from 13 to 28 months. There was no significant relationship between overall survival and neither RAGE nor HMBG1 mRNA expression levels ( $p=0.17, r=0.17$ and $\mathrm{p}=0.31, \mathrm{r}=0.13$ respectively). 
Table 1: clinico-pathological characteristics of the studied cases :

\begin{tabular}{|c|c|c|c|c|}
\hline & \multicolumn{2}{|c|}{$\begin{array}{c}\text { Breast cancer patients } \\
(\mathrm{n}=68)\end{array}$} & \multirow{2}{*}{$\begin{array}{c}\begin{array}{c}\text { Benign breast diseases cases } \\
(\mathrm{n}=63)\end{array} \\
\text { NO. }\end{array}$} \\
\hline & & NO. & $\%$ & \\
\hline & Median & \multicolumn{2}{|c|}{49} & $\mathbf{5 0}$ \\
\hline & Range & \multicolumn{2}{|c|}{$21-82$} & $40-59$ \\
\hline & Median & \multicolumn{2}{|c|}{3.3} & \\
\hline & Range & \multicolumn{2}{|c|}{$1-7.4$} & \\
\hline \multirow{3}{*}{$\begin{array}{l}\text { Differentiation } \\
\text { Grade }\end{array}$} & grade 1 & 3 & 4.5 & \\
\hline & grade 2 & 52 & 76.5 & \\
\hline & grade 3 & 13 & 19.1 & \\
\hline \multirow{4}{*}{ T stage } & T1 & 19 & 27.9 & \\
\hline & $\mathbf{T 2}$ & 38 & 55.9 & \\
\hline & T3 & 9 & 13.3 & \\
\hline & $\mathbf{T 4}$ & 2 & 2.9 & \\
\hline \multirow{4}{*}{ N stage } & No & 5 & 7.4 & \\
\hline & N1 & 19 & 27.9 & \\
\hline & N2 & 28 & 41.2 & \\
\hline & N3 & 16 & 23.5 & \\
\hline \multirow{5}{*}{ Stage } & $\mathbf{I}$ & 4 & 5.9 & \\
\hline & II & 19 & 27.9 & \\
\hline & III & 45 & 66.2 & \\
\hline & Median & \multicolumn{2}{|c|}{5} & \\
\hline & Range & \multicolumn{2}{|c|}{$0-17$} & \\
\hline \multirow{2}{*}{ Recurrence } & Negative & 50 & 73.5 & \\
\hline & Positive & 18 & 26.5 & \\
\hline \multirow{3}{*}{ Molecular type } & Luminal & 29 & 42.6 & \\
\hline & Her-2 & 21 & 30.9 & \\
\hline & Triple negative & 18 & 26.5 & \\
\hline \multirow{2}{*}{$\begin{array}{l}\text { Presence of in- } \\
\text { situ component }\end{array}$} & No & 59 & 86.8 & \\
\hline & Yes & 9 & 13.2 & \\
\hline
\end{tabular}

Table 2: Comparison between control and malignant groups regarding RAGE and HMGB1 mRNA expression . 
Shimaa El-Shafey Soliman et all

\begin{tabular}{|c|c|c|c|c|c|}
\hline & & $\begin{array}{c}\text { Breast } \\
\text { cancer } \\
\text { patients } \\
(\mathbf{n}=68) \\
\end{array}$ & $\begin{array}{l}\text { Benign breast } \\
\text { diseases cases } \\
\quad(n=63)\end{array}$ & Test & P.value \\
\hline \multirow{2}{*}{$\begin{array}{l}\text { HMGB } \\
1\end{array}$} & Median & 8.4 & 0.8 & \multirow{2}{*}{$\mathrm{U}=36$} & \multirow{2}{*}{$<0.000$} \\
\hline & Range & $1.35-89.7$ & $0.04-2.9$ & & \\
\hline \multirow{2}{*}{ RAGE } & Median & 15.6 & 0.8 & \multirow{2}{*}{$\mathrm{U}=\mathbf{1 5}$} & \multirow{2}{*}{$<0.000$} \\
\hline & Range & $2.9-76.8$ & $0.07-3.9$ & & \\
\hline
\end{tabular}

RAGE: receptor for advanced glycation end product, HMGB1: high-mobility group box 1 SD= standard deviation $\quad \mathrm{U}=$ Mann Whitney

Table 3:The association of RAGE mRNA expression level and clinico-pathological characteristics in breast cancer cases

\begin{tabular}{|c|c|c|c|c|c|}
\hline & \multicolumn{4}{|c|}{ RAGE in Breast cancer patients } \\
\hline & & Median & Range & Test & p-value \\
\hline \multicolumn{2}{|l|}{ Age (years) } & & & $\mathrm{r}=0.13$ & 0.32 \\
\hline \multicolumn{2}{|l|}{ Tumor Size $(\mathrm{cm})$} & & & $\mathrm{r}=0.66$ & $<0.001$ \\
\hline \multirow{2}{*}{$\begin{array}{l}\text { Differentiation } \\
\text { Grade }\end{array}$} & grade $1 \& 2$ & 13.5 & $2.9-45.6$ & \multirow{2}{*}{$\begin{array}{c}\mathrm{U}= \\
107.5\end{array}$} & \multirow{2}{*}{$<0.001$} \\
\hline & grade 3 & 20.7 & $15.7-76.8$ & & \\
\hline \multirow{3}{*}{ T stage } & $\mathrm{T} 1$ & 7.5 & $2.9-16.8$ & \multirow{3}{*}{$\begin{array}{c}\mathrm{K}= \\
26.4\end{array}$} & \multirow{3}{*}{$<0.001$} \\
\hline & $\mathrm{T} 2$ & 15.9 & $4.1-45.6$ & & \\
\hline & $\mathrm{T} 3 \& 4$ & 20.7 & $15.7-76.8$ & & \\
\hline \multirow{4}{*}{ N stage } & N0 & 5.6 & $4.1-16$ & \multirow{4}{*}{$\begin{array}{c}\mathrm{K}= \\
28.3\end{array}$} & \multirow{4}{*}{$<0.001$} \\
\hline & $\mathrm{N} 1$ & 7.5 & $4.5-45.6$ & & \\
\hline & $\mathrm{N} 2$ & 14.1 & $2.9-45.6$ & & \\
\hline & N3 & 21.9 & $15.8-76.8$ & & \\
\hline \multirow{2}{*}{ Stage } & I \& II & 5.6 & $4.12-16.6$ & \multirow{2}{*}{$\begin{array}{l}\mathrm{U}= \\
178\end{array}$} & \multirow{2}{*}{$<0.001$} \\
\hline & III & 16.3 & $2.9-76.8$ & & \\
\hline \multicolumn{2}{|c|}{ Number of positive Lymph Nodes } & & & & $<0.001$ \\
\hline \multirow{2}{*}{ Recurrence } & negative & 15.7 & $4.6-76.8$ & \multirow{2}{*}{$\begin{array}{c}\mathrm{U}= \\
331\end{array}$} & \multirow{2}{*}{0.098} \\
\hline & positive & 12.8 & $2.9-65.8$ & & \\
\hline \multirow{3}{*}{ Molecular type } & Luminal & 15.6 & $2.9-45.6$ & \multirow{3}{*}{$\begin{array}{c}K= \\
0.15\end{array}$} & \multirow{3}{*}{0.92} \\
\hline & Her 2 & 16 & $4.3-32.5$ & & \\
\hline & $\begin{array}{c}\text { Triple } \\
\text { negative }\end{array}$ & 13.9 & $4.9-76.8$ & & \\
\hline \multirow{2}{*}{$\begin{array}{l}\text { Presence of insitu } \\
\text { component }\end{array}$} & No & 14 & $2.9-45.6$ & \multirow{2}{*}{$\begin{array}{c}\mathrm{U}= \\
108.5\end{array}$} & \multirow{2}{*}{0.004} \\
\hline & Yes & 19.6 & $12.3-76.8$ & & \\
\hline
\end{tabular}

RAGE receptor for advanced glycation end product $\mathrm{SD}=$ standard deviation $r=$ Spearman correlation coefficient $\quad U=$ Mann Whitney $\quad K=$ Kruskal Wallis

Table 4: The association of HMBG1 mRNA expression level and 
clinico-pathological chacharacteristics in breast cancer patients

\begin{tabular}{|c|c|c|c|c|c|}
\hline & \multicolumn{4}{|c|}{ HMGB1 in Breast cancer patients } \\
\hline & & $\begin{array}{l}\text { media } \\
\mathrm{n}\end{array}$ & Range & Test & $\begin{array}{l}\text { p- } \\
\text { value }\end{array}$ \\
\hline \multicolumn{2}{|l|}{ Age (years) } & & & $\mathrm{r}=0.08$ & 0.46 \\
\hline \multicolumn{2}{|l|}{ Tumor Size (cm) } & & & $r=0.68$ & $\begin{array}{l}<0.00 \\
1\end{array}$ \\
\hline \multirow{2}{*}{$\begin{array}{l}\text { Differentiation } \\
\text { Grade }\end{array}$} & grade $1 \& 2$ & 7.4 & $1.35-85.9$ & $\mathrm{U}=$ & $<0.00$ \\
\hline & grade 3 & 14.5 & $10.7-89.7$ & 115.5 & 1 \\
\hline \multirow{3}{*}{ T stage } & $\mathrm{T} 1$ & 4.8 & $1.35-14.5$ & \multirow{3}{*}{$\begin{array}{c}\mathrm{K}= \\
23.6\end{array}$} & \multirow{3}{*}{$\begin{array}{c}<0.00 \\
1\end{array}$} \\
\hline & $\mathrm{T} 2$ & 9.7 & $1.4-85.9$ & & \\
\hline & T $3 \& 4$ & 14.5 & $10.7-89.7$ & & \\
\hline \multirow{4}{*}{ N stage } & N0 & 3.8 & $3.8-5.2$ & \multirow{4}{*}{$\begin{array}{c}\mathrm{K}= \\
33.8\end{array}$} & \multirow{4}{*}{$\begin{array}{c}<0.00 \\
1\end{array}$} \\
\hline & N1 & 3.8 & $1.35-65.6$ & & \\
\hline & $\mathrm{N} 2$ & 8.4 & $3.9-85.9$ & & \\
\hline & N3 & 18.9 & $10.7-89.7$ & & \\
\hline \multirow{2}{*}{ Stage } & I \& II & 3.8 & $1.35-10.9$ & \multirow{2}{*}{$\mathrm{U}=94$} & $<0.00$ \\
\hline & III & 12.3 & $3.9-89.7$ & & 1 \\
\hline \multicolumn{2}{|c|}{$\begin{array}{l}\text { Number of positive Lymph } \\
\text { Nodes }\end{array}$} & & & $r=0.64$ & $\begin{array}{c}<0.00 \\
1\end{array}$ \\
\hline \multirow{2}{*}{ Recurrence } & negative & 9.4 & $3.2-85.9$ & \multirow{2}{*}{$\begin{array}{c}\mathrm{U}= \\
364.5\end{array}$} & \multirow{2}{*}{0.23} \\
\hline & Positive & 6.7 & $1.35-89.7$ & & \\
\hline \multirow{3}{*}{ Molecular type } & Luminal & 7.4 & $1.4-65.6$ & \multirow{3}{*}{$\begin{array}{l}K= \\
0.64\end{array}$} & \multirow{3}{*}{0.73} \\
\hline & Her 2 & 8.4 & $3.2-74.9$ & & \\
\hline & $\begin{array}{l}\text { Triple } \\
\text { negative }\end{array}$ & 10.3 & $1.4-89.7$ & & \\
\hline \multirow[b]{2}{*}{$\begin{array}{l}\text { Presence of } \\
\text { insitu component }\end{array}$} & No & 7.5 & $1.4-85.9$ & \multirow[b]{2}{*}{$\mathrm{U}=107$} & \multirow[b]{2}{*}{0.004} \\
\hline & Yes & 29.4 & $7.7-89.7$ & & \\
\hline
\end{tabular}

HMGB1: high-mobility group box $1 \mathrm{SD}=$ standard deviation $\quad \mathrm{r}=$

Spearman correlation coefficient $\quad U=$ Mann Whitney $K=$ Kruskal Wallis 


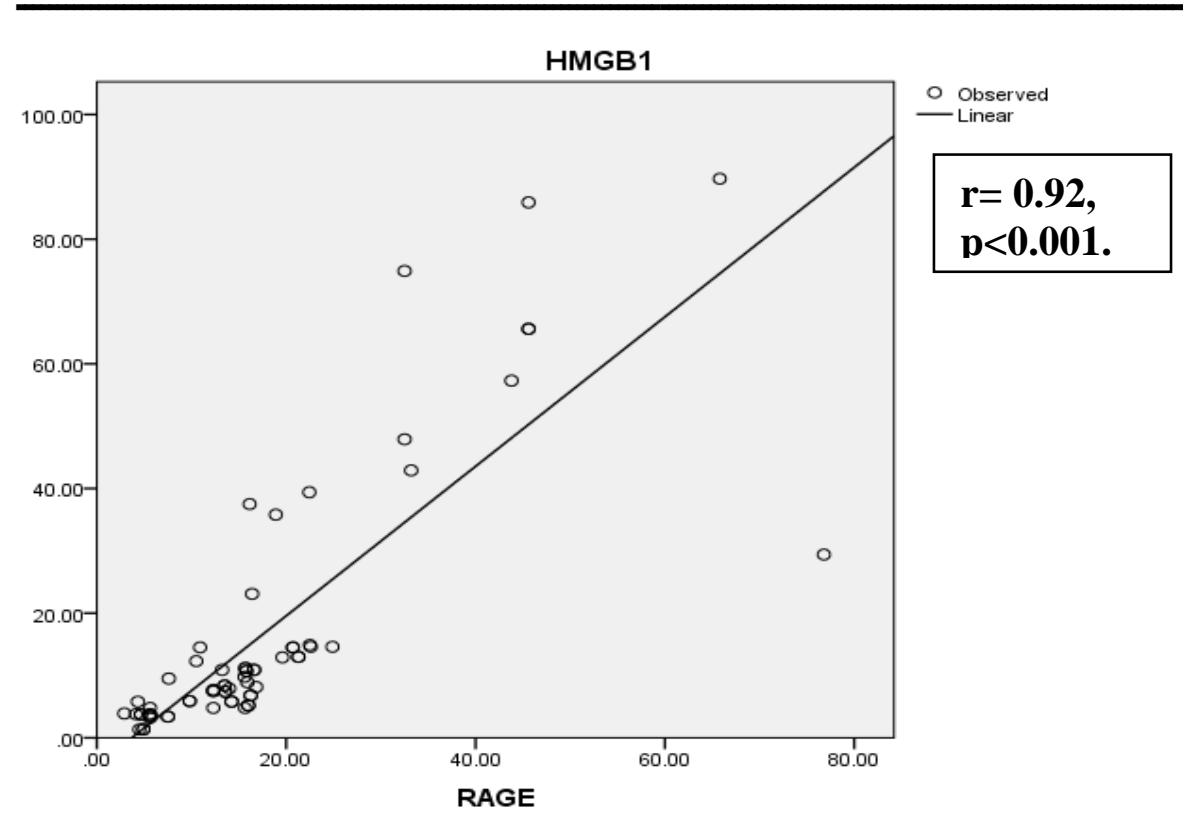

\section{Figure 3: Significant positive linear correlation between RAGE and HMBG1}

\section{DISCUSSION}

RAGE and its ligand HMGB1 are considered as critical mediators of cancer development and progression through activation of oncogenic signaling cascades linked to tumor cell proliferation and metastasis (Sohun and Shen, 2016). Based on the results of this study, RAGE-HMGB1 axis displayed higher expression levels in breast cancer tissues compared to benign group announcing for its involvement in tumour birth. Of note, there was collegial overexpression of both RAGE and HMGB1 which is proved, in this study, by the significant positive correlation between RAGE and HMGB1 levels. Previous reports augment our findings regarding HMGB1 overexpression in breast cancer (Stoetzer et al., 2013, Sun et al., 2015, ke et al., 2017). Within tumor cores many cells die by necrosis owing to the misery tumor microenvironment of hypoxia and nutrient shortage hence passive release of HMGB1 (Exner et al., 2016). Once released, it reacts with RAGE to nourish the 
inflammatory tumor microenvironment through activation of nuclear factor kappa B (NF- $\kappa \mathrm{B})$ and release of proinflammatory cytokine (Chen et al., 2014, Paek et al., 2016). Also, extracellular HMGB1 increases mitochondrial RAGE expression and translocation, which in turn increases mitochondrial complex I activity and ATP generation encouraging tumor growth (Kang et al., 2014).

This study demonstrated that RAGE-HMGB1 co-expression in cancerous tissues was significantly associated with high tumour grade, advanced T stage, lymph node metastasis, stage III, and presence of in situ component. Moreover, both expression levels showed significant positive correlation with tumor size and number of positive lymph node, wih no significant relation to the molecular type. These findings make evident that RAGE-HMGB1 system is linked to aggressive breast cancer attitude representing a prognostic biomarker of remarkable clinical and therapeutic significance.

The RAGE-HMGB1 interply pushes for tumor growth and metastasis by possible mechanisms; (1) activation of mitogen-activated protein kinases, Rac1, NF- $\kappa \mathrm{B}$ (Chen et al., 2014), extracellular signal regulated kinase $1 / 2$ (ERK 1/2), and the protein kinase $B$ pathway (Angelopoulou et al., 2016). This in turn results in the expression of matrix metalloproteinases paving the way for tumor invasion (Ohmori et al., 2011), (2) induction of expression of proangiogenic growth factors and their receptors enhancing angiogenesis (kang et al., 2013), (3) HMGB1 enhances tumor cell motility by activating endothelial growth factor favouring invasion and metastasis (Sparatore et al., 2005), (4) Escape from the host immune surveillence (Sohun and Shen, 2016).

Similar to our findings, several reports potentiate the link between RAGE and HMGB1 and the malignant virulence of cancer (Tesarova et al., 2016, Dhumale et al., 2015). Kostova et al., investigated tissue samples from several cancers including 72 cases of ductal breast carcinoma and stated that beside the state of tumor differentiation, cancer prognosis can rely on HMGB1-RAGE expression and their 
exact location in the cell (Kostova et al., 2010). Nankali et al., 2016 and his collegues, in their RT-PCR based study, found RAGE mRNA up-regulation in breast cancerous tissue that was significantly associated wih advanced-stage and triple-negative breast tumors, node-positive tissues and tumor size. Sun et al., 2015, demonstrated the close relation between HMGB1 levels and TNM stage, differentiation, and metastasis confirming its incrimination in breast cancer biological behaviour but with no association with patient age, tumor size, or HER-2/neu levels. Chang et al., 2014 . in an immunohistochemistry based study on 60 patient with infiltrative ductal carcinoma, revealed higher HMGB1 expression in advanced stages and lymph node metastasis tissues considering it as a biomarker of unfavourable prognosis, but in contrast to us, HMGB1 showed positive correlation with HER-2. This discrepancy may be due to different study methodology and different racial background of patients.

In this study, the observed significant correlation between tumor size and RAGE-HMGB1 overexpression, was in agreement with other studies (Sippel et al., 2008, Thompson et al., 2009). It well established that, prognosis is profoundly dependent on tumor size (Michaelson et al., 2003). So this correlation indicates their participation in tumor growth and expansion.

Different studies clarified the RAGE-HMGB1 critical role in breast cancer biology by their blocking, resulting in inhibition of breast cancer cells proliferation and metastasis (Kang et al., 2013, Radia e al., 2013 and Dhumale et al., 2015).

Our study revealed that, there was no significant relationship between overall survival and neiher RAGE nor HMGB1 expression levels. Similary, in a meta-analysis conducted by $\mathbf{W u}$ et al, to assess the prognostic value of HMGB1 expression in cancer, they noticed that HMGB1 overexpression was significantly associated with survivals under all studies circumstances except when the detection method of qRT-PCR was used. They explained this, at least in part, by the limited available RT-PCR based studies and their small sample size (Wu et 
al., 2016).

\section{Conclusion:}

From this study, it could be concluded that the association of RAGE and HMGB1 overexpression with aggressive breast cancer phenotypes. Thus they may consititute prognostic biomarkers with therapeutic potential.

\section{REFERENCES}

Angelopoulou E, Piperi C , Adamopoulos C and Papavassiliou AG (2016): Pivotal role of high-mobility group box 1 (HMGB1) signaling pathways in glioma development and progression.J Mol Med ; 94:867-874.

Bierhaus A, Humpert PM, Morcos M, Wendt T and Chavakis T (2005): Understanding RAGE, the receptor for advanced glycation end products. J. Mol. Med. 83, 876-886. Bond HM, Scicchitano S, Chiarella E, Amodio N, Lucchino V, Aloisio A, Montalcini Y, Mesuraca $M$ and Morrone G (2018): ZNF423: A New Player in Estrogen Receptor-Positive Breast Cancer. Front Endocrinol (Lausanne). 18;9:255.

Chang B, Wang X, Gao S, Zhao B, Wang W, Yang S, Chu Q and Yu S (2014): Clinical signification of high-mobility group box 1 protein (HMGB1) expression in infiltrating ductal carcinoma breast tissue. Chinese-German J Clin Oncol; Vol. 13, No. 5, P215-P219.

Chen RC, Yi PP, Zhou RR, Xiao MF, Huang ZB, Tang DL, Huang $Y$ and Fan XG (2014): The role of HMGB1-RAGE axis in migration and invasion of hepatocellular carcinoma cell lines. Mol Cell Biochem 390:271-280.

Dorak M(2004): Real-time PCR. Clinical Chemistry;50:1680-1693.

Dhumale SS, Waghela BN1 and Pathak C (2015): Quercetin protects necrotic insult and promotes apoptosis by attenuating the expression of RAGE and its ligand HMGB1 in human breast adenocarcinoma cells. IUBMB Life. ;67(5):361-373.

Edge SB, Byrd DR and Compton CC (editors). Breast. In: AJCC cancer staging manual. 7th edition. New York, NY: Springer, 
2010:347-376.

Elston CW and Ellis IO(1991): Pathological prognostic factors in breast cancer. The value of histological grade in breast cancer: experience from a large study with long-term follow-up. Histopathology;19(5):403-410.

Exner R, Sachet M, Arnold T, Zinn-Zinnenburg M, Michlmayr A, Dubsky P, Bartsch R ,et al. (2016): Prognostic value of HMGB1 in early breast cancer patients under neoadjuvant chemotherapy. Cancer Med;5(9):2350-2358.

Goodwin GH, Sanders C and Johns EW(1973): A new group of chromatinassociated proteins with a high content of acidic and basic amino acids. Eur J Biochem;38(1):14-19.

Goldhirsch A, Wood WC, Coates AS, Gelber RD, Thürlimann B, Senn HJ, et al.( 2011): Strategies for subtypes-dealing with the diversity of breast cancer: highlights of the St. Gallen international expert consensus on the primary therapy of early breast cancer. Ann Oncol. ;22(8):1736-47

He SJ, Cheng J, Feng X, Yu Y, Tian L and Huang Q (2017): The dual role and therapeutic potential of high-mobility group box 1 in cancer. Oncotarget.16;8(38):64534-64550.

Kang R, Zhang Q, Zeh HJ, Lotze MT and Tang D (2013): HMGB1 in Cancer: Good, Bad, or Both? Clin Cancer Res . 2013 August 1; 19(15): 4046-4057.

Kang R, Tang D and Schapiro NE(2014): The HMGB1/RAGE inflammatory pathway promotes pancreatic tumor growth by regulating mitochondrial bioenergetics. Oncogene 2014;33:567-577.

Ke S, Shi H, Shi W and Chen Y (2017): Original Article Downregulation of HMGB1 induces apoptosis and inhibits invasion and migration of MCF-7 breast cancer cells through targeting SMARCC1. Int J Clin Exp Pathol;10(3):2764-2773.

Kostova N, Zlateva S, Ugrinova I and Pasheva E (2010): The expression of HMGB1 protein and its receptor RAGE in human malignant tumors. Mol Cell Biochem;337(1-2): 251-258. 
Michaelson JS, Silverstein M, Sgroi D, Cheongsiatmoy JA, Taghian A, Powell S, Hughes K, Comegno A, Tanabe KK and Smith B(2003): The effect of tumor size and lymph node status on breast carcinoma lethality. Cancer; 98: 2133-2143.

Nankali M, Karimi J, Goodarzi MT, Saidijam M, Khodadadi I, Razavi ANE, Rahimi F (2016): Increased Expression of the Receptor for Advanced Glycation End-Products (RAGE) Is Associated with Advanced Breast Cancer Stage.Oncol Res Treat;39:622-628.

Nguyen A, Bhavsar S, Riley E, Caponetti G and Agrawal D (2016): Clinical Value of High Mobility Group Box 1 and the Receptor for Advanced Glycation Endproducts in Head and Neck Cancer:ASystematic Review.Int Arch Otorhinolaryngol 2016;20:382389.

Ohmori H, Luo Y and Kuniyasu H(2001): Non-histone nuclear factor HMGB1 as a therapeutic target in colorectal cancer. Expert Opin Ther Targets;15(2):183-193.

Paek J, Lee M, Nam EJ, Kim SW and Kim YT (2016): Clinical impact of high mobility group box 1 protein in epithelial ovarian cancer. Arch Gynecol Obstet. ;293(3):645-50.

Radia AM, Yaser AM, Ma X, Zhang J, Yang C, Dong Q, et al (2013): Specific siRNA targeting receptor for advanced glycation end products (RAGE) decreases proliferation in human breast cancer cell lines. Int J Mol Sci 2013; 14: 7959-7978.

Rai V(2018): Targeting HMGB-1 in Cancer and Immunomodulation with Vitamin D: Time to Focus and Research. J Oncol Res Forecast; 1(2): 1008.

Sippel RS, Elaraj DM, Khanafshar E, Zarnegar R, Kebebew E, Duh QY and Clark OH(2008): Tumor size predicts malignant potential in Hürthle cell neoplasms of the thyroid. World J Surg ; 32: 702-707.

Sohun $M$ and Shen $H$ (2016): The implication and potential applications of high-mobility group box 1 protein in breast cancer. 
Ann Transl Med.;4(11):217-221.

Sparatore B, Patrone M, Passalacqua M, et al(2005): Activation of A431 human carcinoma cell motility by extracellular high-mobility group box 1 protein and epidermal growth factor stimuli. Biochem J;389 Pt 1: 215-221.

Sparvero LJ, Asafu-Adjei D, Kang R, Tang D, Amin N, Im J , et al. (2009): RAGE (Receptor for Advanced Glycation Endproducts), RAGE ligands, and their role in cancer and inflammation. J Transl Med 2009;17;7:17.doi: 10.1186/1479-5876-717.

Stapleton JM, Mullan PB, Dey S, Hablas A, Gaafar R, Seifeldin IA, et al(2011): Patient-mediated factors predicting early and latestage presentation of breast cancer in Egypt. Psychooncology:20(5):532-37.

Stoetzer OJ, Fersching DM, Salat C, et al.(2013): Circulating immunogenic cell death biomarkers HMGB1 and RAGE in breast cancer patients during neoadjuvant chemotherapy. Tumour Biol;34(1):81-90.

Sun S, Zhang W, Cui Z, Chen Q, Xie P, Zhou C, Liu B, Peng X and Zhang Y(2015): High mobility group box-1 and its clinical value in breast cancer. Onco Targets Ther. 2015; 8:413-419.

Tesarova P, Kalousova M, Zima T and Tesar V (2016): HMGB1, S100 proteins and other RAGE ligands in cancer - markers, mediators and putative therapeutic targets. Biomed Pap Med Fac Univ Palaky Olomouc Czech Repub.;160(1):1-10.

Thompson RH, Kurta JM, Kaag M, Tickoo SK, Kundu S, Katz D and Nogueira L(2009): Tumor size is associated with malignant potential in renal cell carcinoma cases. J Urol ; 181: 2033-2036.

Van Beijnum JR, Nowak-Sliwinska $P$, van den Boezem $E$, Hautvast P, Buurman WA and Griffioen A(2012): Tumor angiogenesis is enforced by autocrine regulation of high-mobility group box 1. Oncogene. 2012. 
Wang D, Li T,Ye G, Shen Z, Hu Y, Mou T, etal(2015): Overexpression of the Receptor for Advanced Glycation Endproducts (RAGE) Is Associated with Poor Prognosis in Gastric Cancer. PloS ONE 10(4): e0122697.

Wang E, Miller L, Ohnmacht G, Liu E and Marincola F(2000): High-fidelity mRNA amplification for gene profiling. Nature Biotechnology. 2000;18(4):457-459.

Wang W, Jiang H, Zhu H, Zhang H, Gong J, Zhang L, Ding Q (2013): Overexpression of high mobility group box 1 and 2 is associated with the progression and angiogenesis of human bladder carcinoma. Oncol Lett.;5(3):884-888.

Wittwer C, Boeck S, Heinemann V, Haas M, Stieber P, Nagel D, et al(2013): Circulating nucleosomes and immunogenic cell death markers HMGB1, sRAGE and DNAse in patients with advanced pancreatic cancer undergoing chemotherapy. Int J Cancer; 133: 26192630.

Wu T, Zhang W, Yang G, Li H, Chen Q, Song R, Zhao L (2016): HMGB1 overexpression as a prognostic factor for survival in cancer: a meta-analysis and systematic review. Oncotarget. 2016 Aug 2;7(31):50417-50427.

Zheng T1, Wang A1, Hu D1, Wang Y (2017): Molecular mechanisms of breast cancer metastasis by gene expression profile analysis. Mol Med Rep. ; 16(4): 4671-4677. 


\section{الملخص العربي}

تقييم مستوى التعبيز الجينى لمستقبل الناتج التهائى التحللى المتقدم (RAGE)

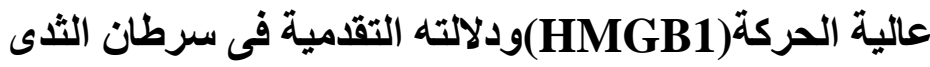

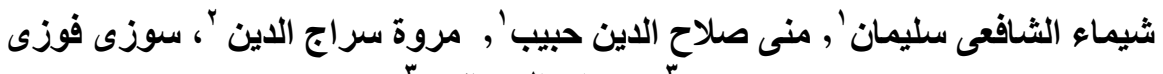

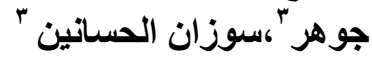

اقسام الكيميـاء الحيــوية الطبيـة والباثولوجى والاورام - كلية الطب - جامعة المنوفية

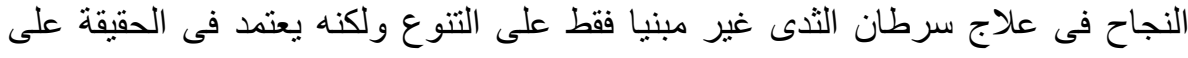

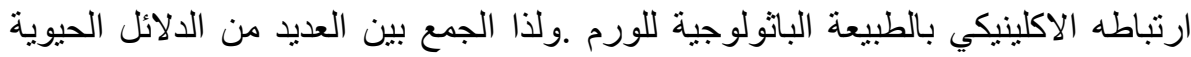

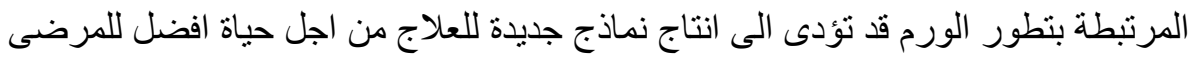

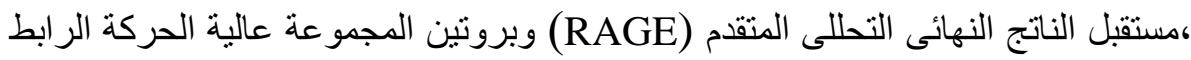

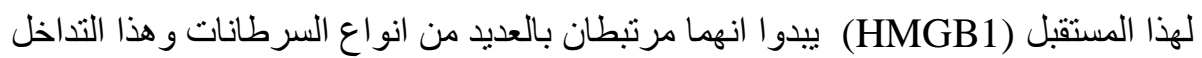

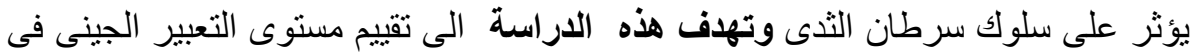

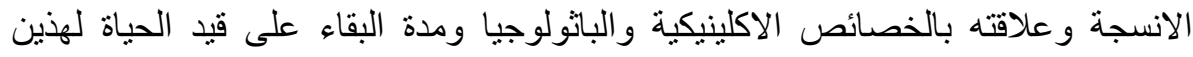

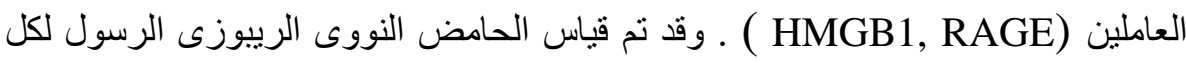
من (HMGB1, RAGE) بواسطه التفاعل التسلسلي للبلمره الزمنيه. و قد أظهرت النّائل النتائج

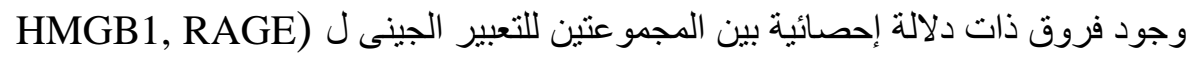

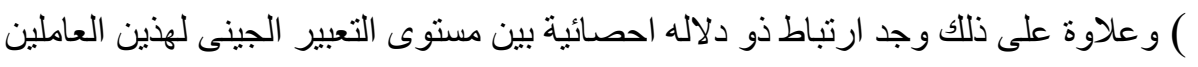

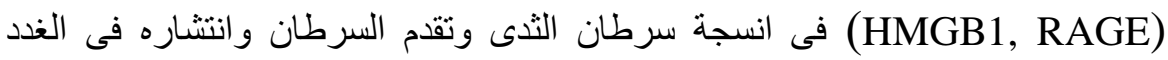
الليمفاوية ونم ايجاد علاقة ايجابية ذات دلالة احصائية بين مستوى التعبير الجينى لهذين العاملين (HMGB1, RAGE)وحجم السرطان و عدد الغدد اليمفاوية الايجابية المصابة لابنة

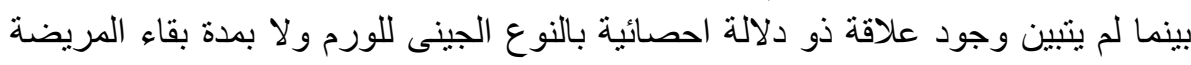

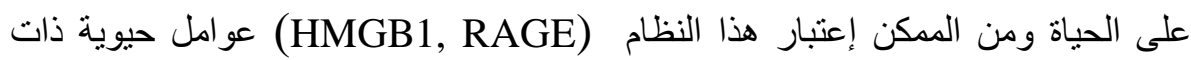
دلالة تقدمية من الناحية الاكلينيكية و العلاجية لسرطان العنان الثنى . 